\title{
What does research tell high school teachers about student motivation for test performance?
}

DOI:

10.1080/02643944.2018.1453858

\section{Document Version}

Accepted author manuscript

Link to publication record in Manchester Research Explorer

\section{Citation for published version (APA):}

Flitcroft, D., \& Woods, K. (2018). What does research tell high school teachers about student motivation for test performance? Pastoral Care in Education. https://doi.org/10.1080/02643944.2018.1453858

\section{Published in:}

Pastoral Care in Education

\section{Citing this paper}

Please note that where the full-text provided on Manchester Research Explorer is the Author Accepted Manuscript or Proof version this may differ from the final Published version. If citing, it is advised that you check and use the publisher's definitive version.

\section{General rights}

Copyright and moral rights for the publications made accessible in the Research Explorer are retained by the authors and/or other copyright owners and it is a condition of accessing publications that users recognise and abide by the legal requirements associated with these rights.

\section{Takedown policy}

If you believe that this document breaches copyright please refer to the University of Manchester's Takedown Procedures [http://man.ac.uk/04Y6Bo] or contact uml.scholarlycommunications@manchester.ac.uk providing relevant details, so we can investigate your claim.

\section{OPEN ACCESS}




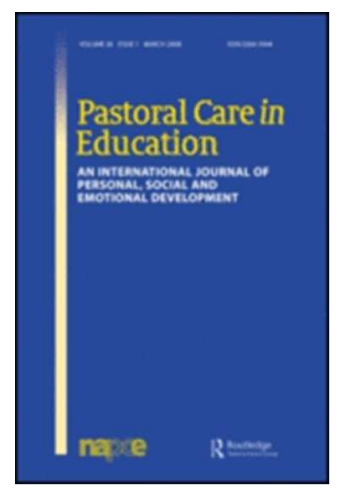

\section{What does research tell high school teachers about student} motivation for test performance?

\begin{tabular}{|r|l|}
\hline Journal: & Pastoral Care in Education \\
\hline Manuscript ID & RPED-2017-0034.R1 \\
\hline Manuscript Type: & Original Article \\
\hline Keywords: & $\begin{array}{l}\text { student motivation, teacher behaviour, teacher knowledge, academic } \\
\text { assessment, academic performance }\end{array}$ \\
\hline \multicolumn{2}{|l}{} \\
\hline
\end{tabular}

SCHOLARONE ${ }^{\text {M }}$

Manuscripts 


\section{Abstract}

'Motivation' is a significant concept for teachers and students during programmes of learning which lead explicitly to high stakes assessments and examinations. This systematic literature review surveys current research evidence to find out how secondary school teachers use motivational strategies specifically in respect of student academic assessment and performance. Six research studies were identified describing the behaviours secondary school teachers engaged in to improve student performance in assessment. Taken together, the studies presented show the importance of teacher behaviours to students' academic performance, with both positive and negative impacts. The review highlights a need for further research on teacher knowledge of the effects of teacher behaviour upon the motivation of students. The review recommends collaboration between teachers and students specific to the context of learning programmes that lead to high-stakes assessments, in order to provide a locally sensitive knowledge base for teachers' practice.

Keywords: student motivation, teacher behaviour, teacher knowledge, academic assessment, academic performance 


\section{Introduction}

\section{Learner engagement and motivation}

Different approaches have been taken to the engagement of students in their learning and assessment experiences. Since the inception of the United Nations Convention on the Rights of the Child (UN, 1989) learner engagement has been particularly promoted through a range of practices that focus upon gathering and utilizing student feedback in order to enhance participation in educational structures and processes (e.g. Adderley et al., 2015; Burton, Smith \& Woods, 2010; DCSF, 2010; DfE, 2014b; Groundwater-Smith \& Mockler, 2016; Harding \& Atkinson, 2009; HM Government, 2002; White \& Rae, 2016). Extending beyond this more

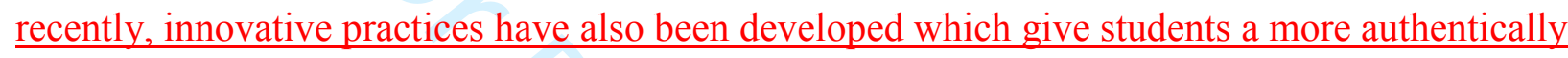
$\underline{\text { collaborative role to engender dialogue between students and teachers, and co-creation of }}$ educational processes (e.g. Bourke \& Loveridge, 2016; Hall, 2017).

Other research has considered the consequences of different assessment regimes upon student engagement and well-being (e.g. Scott, Webber, Lupart, Aitkin \& Scott, 2014; Stobart, 2008). Debate has centred particularly upon the relative merits and balance of summative assessment (assessment of learning) and formative assessment (assessment for learning), with the $\underline{\text { latter viewed as being more meaningful and motivating for students within a teaching and }}$ learning context (Stobart, 2008). At key transition points, however, students face the challenge of summative assessments, which often focus on a narrow or 'reductionist' range of grade outcomes, and which are considered to be high-stakes for both students and teachers (e.g. GCSEs in England). Furthermore, the increasing influence of high stakes assessments within 'performative' educational systems of developed nations are acknowledged to be increasing strain on both students and teachers alike (Rodway et al., 2016; Williams, Ryan \& Morgan, 2014). Unlike the areas of teaching and learning, very little use has been made of student participation and direct feedback in relation to high stakes examinations, and the point has been made that high-stakes systems are in any case highly resistant to change (Davis, 1993; Mathews, 1985; Stobart, 2008; Woods, 2003). So, whilst concepts of learner engagement, authentic collaboration, and formative assessment for learning are abundantly evident in research on teaching and learning, research on learner engagement in relation to summative assessment ('learning for assessment') has taken a more positional, and less socially constructed, approach. 
As a first step in motivating students towards learning in high stakes assessments, teachers have to teach as effectively as possible (Department for Children Schools and Families, 2008; Shulman \& Sykes, 1986; Tamir, 1987) Coe, Aloisi, Higgins and Major (2014) propose six components found in effective teaching: pedagogical content knowledge, quality of instruction, classroom climate, classroom management, teacher beliefs and professional behaviours. Classroom climate centres on the interactions between teachers and students, showing the importance of teacher language and interactions with students in the classroom. Perhaps surprisingly, some studies suggest that praise can be counter-productive for some learners, and that teacher encouragement, or sympathy after failure, to low attaining students may be perceived as having low ability expectations (Dweck, 1999; Hattie \& Timperley, 2007; Stipek, 2010).

Contemporary theories of motivation propose that behaviour is underpinned by a belief that it will lead to a desired outcome (Deci \& Ryan, 2000) and recent research proposes that aspects such as goal type and anticipated success affect motivation (Bong, Cho, Ahn \& Kim, 2012; Putwain \& Remedios, 2014; Ryan \& Deci, 2000). Research comparing those with 'authentic motivation' to those who are 'externally controlled', has found the former to have more interest, excitement and confidence which leads to enhanced performance, persistence, creativity, and self-esteem (Deci \& Ryan, 1991; Deci \&Ryan, 1995). 
Self-Worth Theory (SWT) (Covington, 1984) proposes that student motivation is based on the student's need to protect their sense of self-worth, to which self-perceptions of abilities are critical; students' perceptions of their ability is a primary activator of their achievement behaviour and so students are driven to succeed because achievement promotes a reputation of ability. Alternatively, Self-Determination Theory (SDT) proposes that motivation is based on innate psychological needs for competence, autonomy and relatedness (Ryan \& Deci, 2000). Accordingly, when school teachers need to motivate their students, they need to understand differences in student motivations, ranging from unwillingness through passive compliance to active commitment. Control Value Theory (CVT), however, focuses on achievement emotions determined by an individual's perception of their control and value of the activity and outcomes (Pekrun, 2000, 2006). CVT does not assume that appraisals of situations are consciously made but instead through recurring activities and outcomes and their attaching emotions (Pekrun \& Stephens, 2010), proposing routes by which achievement emotions may influence performance (e.g. effects on mood, cognitive load) (Pekrun \& Stephens, 2010; Schunk, Pintrich \& Meece, 2008). CVT suggests teachers can improve student motivation by facilitating development of emotional competency in learning and performance (Astleitner, 2000; Pekrun, Frenzel, Goetz \& Perry, 2007).

Given the significance of student motivation to teachers in supporting student engagement in high-stakes assessments, evidence to find out how high school teachers use motivational strategies specifically in respect of student assessment performance.

\section{Method of the review}

\section{Literature search strategy and selection of research}

The present study addressed the following literature review question:

What motivational behaviours do secondary school teachers engage in, in respect of student performance in assessment and why?

The PRISMA framework (Moher, Liberati, Tetzlaff, \& Altman, 2009) was used to identify, screen and select relevant research papers. The rationale for this was to be 'aggregative' $\underline{\text { in our data synthesis so as to ensure the review included all relevant studies and therefore avoid }}$ 
bias in the reporting of our findings (Gough, Oliver, Thomas, 2013, p.15). The research papers within the literature review were sourced between April and May 2015 from across a number of databases, including Web of Science, EBSCO, PsycINFO: Ovid online, JSTOR, Education Resources Information Centre (ERIC), British Library EThOS and Google Scholar. The following search terms were applied to the abstracts of papers: 'motivation AND teacher behaviour AND academic performance'. In addition, consultation with an academic expert in the field of teacher behaviour, student motivation and academic performance gave further indications for key research papers. Finally, papers were also obtained through 'reference harvesting' of sourced papers (cf. Woods, Bond, Humphrey, Symes \& Green, 2011).

653 papers were initially sourced, of which 608 were excluded after screening of titles. The remaining 45 papers were screened against the following inclusion criteria by reading of abstracts:

- Published in English

- Entailed primary data collection

- Research was based on quantitative or qualitative investigation or evaluation

- Sample age range of 11-16 years of age (UK secondary equivalent) or a reflection on school experience during the ages of 11- 16 years of age

- Academic achievement must be a measure

At this stage, a further 30 studies were excluded as they did not meet the criteria outlined above. After removing duplicates, 6 papers remained and were examined in full.

\section{Quality assessment of research}

Quality assurance of reported research is important as it ensures that unreliable research and findings are excluded from the review. In order to accurately review the quality of research, each paper was read at least twice. Drawing upon key sources for quality of research reporting, a specifically devised framework for the evaluation of quantitative investigative studies was used (cf. Choi, 1998; Cohen, Manion \& Morrison, 2007; Geneady et al., 2007; Wallace \& Wray, 2011). The framework, available upon request from the authors, identifies 15 features relating to data gathering, analysis, and interpretation, such as: appropriateness and comprehensiveness of data gathering methods; appropriate sampling and response rate maximization; appropriateness 
of statistical and missing data analyses; and consideration of research limitations. Attributing one point for each evident framework feature, each selected research paper was given a total evaluation score ranging from $0-15$. The quality of qualitative investigative research was reviewed using a framework utilised in a published systematic literature review (Woods et al., 2011) which identifies 12 criteria including sampling rationale, analysis close to the data and transferable conclusions. Attributing one point for each evident framework feature, each selected research paper was given a total evaluation score ranging from 0-12. For comparability, total quality evaluation scores were converted to percentages. Reports which scored less than 33\% were deemed to be 'low quality' and were to be excluded from the review. Reports which scored between $33 \%$ and $66 \%$ were viewed as 'moderate quality' and those which scored above $66 \%$ were viewed as 'good quality'.

\section{Review of research: teacher behaviour and student motivation for examination performance}

\section{Overview of studies included}

Six studies reported motivational behaviours secondary school teachers engaged in to improve student performance in assessment (LevpuÅÄek \& ZupanÄiÄ, 2009; Putwain \& Remedios, 2014; Putwain \& Roberts, 2012; Siegle, Rubenstein \& Mitchell, 2014; Wentzel, 1997, 2002).

\section{Characteristics of Research}

Overview of Methodological Quality

The overall range in rated quality was 53\% (Putwain \& Roberts, 2012) to 87\% (Putwain \& Remedios, 2014). Five studies had a rating over 60\% (LevpuÅÄek \& ZupanÄï̈, 2009; Putwain \& Remedios, 2014; Siegle et al., 2014; Wentzel, 1997, 2002), suggesting the majority of studies were good quality.

\section{Study Design}

Five studies used a quantitative method design (LevpuÅÄek \& ZupanÄiÄ, 2009; Putwain \& Remedios, 2014; Putwain \& Roberts, 2012; Wentzel, 1997, 2002). These studies collected data through questionnaires and rating scales and compared results to academic grades. One study used a qualitative method design (Siegle et al., 2014) and involved the use of focus groups 
to gather data. Two of the studies (LevpuÅÄek \& ZupanÄï̈, 2009; Putwain \& Roberts, 2012) focused solely on student motivation in Mathematics, which may limit the generalisibility of findings; conversely, the other four studies do not differentiate student subject focus and so may conceal important subject-specific variations.

\section{Sample Characteristics}

Sample sizes ranged from 28 (Siegle et al., 2014) to 472 (Wentzel, 2002). Four of the studies involved only pupils (LevpuÅÄek \& ZupanÄï̈, 2009; Putwain \& Remedios, 2014; Siegle et al., 2014; Wentzel, 1997). These were either from a middle school (LevpuÅÄek \& ZupanÄï̈, 2009; Siegle et al., 2014; Wentzel, 1997) or a secondary school (Putwain \& Remedios, 2014). One of the studies involved only teachers from a secondary school (Putwain \& Roberts, 2012) but was included in the review as the authors felt it gave an insight to the reason behind teachers' behaviours. One of the studies involved both pupils and teachers from a middle school (Wentzel, 2002). Two of the studies focused on math performance as the measure (LevpuÅÄek \& ZupanÄï̈, 2009; Putwain \& Remedios, 2014). Two studies drew their sample from suburban schools (Wentzel, 1997, 2002). One study drew their sample from a mixture of rural and urban schools (LevpuÅÄek \& ZupanÄiÄ, 2009). The remaining three studies did not report the geographic location of the sample (Putwain \& Remedios, 2014; Putwain \& Roberts, 2012; Siegle et al., 2014). One of the studies involved $10^{\text {th }}$ grade students (UK Year 11 equivalent) (Putwain \& Roberts, 2012). Two studies involved $8^{\text {th }}$ grade pupils (UK Year 9) (LevpuÅÄek \& ZupanÄiÄ, 2009; Wentzel, 1997). One of the studies involved $6^{\text {th }}$ grade pupils (UK Year 7) (Wentzel, 2002). One of the studies involved freshman university students reflecting upon their time at high school (Year 10-13 UK) (Siegle et al., 2014).

\section{Negative impact on students' test performance}

Of the six reviewed studies, two found a negative impact of teachers' use of fear appeals and negative feedback on students' academic performance (Putwain \& Remedios, 2014; Wentzel, 2002). Putwain and Remedios (2014) found a significant negative correlation between high stake examination performance and perceived fear appeals frequency $(r=-.39, n=347, p<.001)$ and high stake examination performance and Perceived Threat $(\mathrm{r}=-.28, \mathrm{n}=347, \mathrm{p}<.001)$ and Wentzel (2002) found a negative correlation between classroom grades and negative feedback $(\mathrm{r}=.21$, $\mathrm{n}=452, \mathrm{p}<.001)$. Both research papers proposed that their results were linked with the students' 
perception of threat and lowered self-determined motivation. From a mediational model, Putwain and Remedios (2014) found that self-determined motivation predicted a higher high stake examination score $(\beta=.13, p=.001)$, perceived threat predicted a lower high stake examination score $(\beta=-.34, p<.001)$ and a greater frequency of perceived fear appeals predicted a lower high stake examination score $(\beta=-.1302, \mathrm{p}<.001)$. This led them to conclude two possible mediational routes from fear appeals to high stake examination Mathematics scores via self-determined motivation. First, higher perceived threat predicts lower self-determined motivation which predicts a lower high stake examination score. Alternatively, greater frequency of fear appeals predicts lower self-determined motivation which predicts a lower high stake examination score.

The paper by Putwain and Remedios (2014) was the only reviewed piece of research to explicitly reference a psychological theory of motivation (SDT). Therefore, the utilisation of theories of motivation appears to be lacking in the education system and, notably, this researcher's previous literature review searches found no current research that assesses teachers' knowledge or understanding of student motivation. Yet the significant influence of the role of the teacher on students' academic performance would suggest that theories of motivation should be utilised in teacher preparation programs so teachers are fully equipped to empower students in their learning.

\section{Positive impact on students' test performance}

Of the six reviewed studies, four found behaviors which have a positive relationship with students' test performance (LevpuÅÄek \& ZupanÄiÄ, 2009; Siegle et al., 2014; Wentzel, 1997; Wentzel, 2002).

LevpuÅÄek \& ZupanÄiÄ (2009) found a significantly positive correlation between Mathematics achievement and perceived academic support $(\mathrm{r}=.25, \mathrm{n}=365, \mathrm{p}<.01)$, academic pressure $(\mathrm{r}=.25, \mathrm{n}=365, \mathrm{p}<.01)$ and mastery goal [i.e. a goal to master learning content] $(\mathrm{r}=.25$, $\mathrm{n}=365, \mathrm{p}<.01$ ). From multiple regressions analysis, the researchers found that academic pressure and mastery goal had a significant indirect positive effect on Mathematics achievement ( $\beta=.09$, $\mathrm{t}=3.03$ and $\beta=.07, \mathrm{t}=2.77$, respectively), which was mediated through the students' self-efficacy in Mathematics $(\beta=.36, \mathrm{t}=5.84$ and $\beta=.28, \mathrm{t}=4.19$ respectively).

Siegle et al. (2014) found that students needed to perceive their teacher as 'caring' to have an impact on their motivation. Students reported their teachers as 'inspiring' when they 
fostered meaningful relationships with their students. They accomplished this by demonstrating that they knew the students personally for example, by tailoring learning to suit students' individual styles of learning, being interested in helping them to succeed, and by attending school events in which their students were involved. Students also reported that it was important for teachers to show how knowledgeable they are, and they wanted to feel like teachers knew more than they did. They reported a high level of motivation when teachers were able to link the course to personal experiences and real life current events. Also students reported to be more engaged with learning and more motivated when they perceived the class activity to be: of value and worth time spent; involve challenging content; relate to depth and breadth of the subject; be well paced. Finally, teachers needed to have a variety of content delivery methods which suited different style of learners and provided variety in their classrooms.

Wentzel (1997) found a significant positive correlation between perceived caring from teachers and academic performance $(\mathrm{r}=.0918, \mathrm{n}=248, \mathrm{p}<.001)$. Students were also asked characteristics of a caring and uncaring teacher. The responses were initially coded into six categories: modelling, democratic interactions, expectations for behaviour, nurturance, rule setting and other. The largest representation of responses for characteristics of a caring or uncaring teacher surrounded expectations for behaviour (43\% for caring teachers and $28 \%$ for uncaring teachers). This code was divided in to two sub-codes: 'student as a person' focuses upon 'a recognition of a student's individuality, and concern with the student's nonacademic functioning'; 'student as a learner' focuses upon 'a recognition of the student as having unique academic skills, problems and contributions to make to the class' (Wentzel, 1997, p416).

Wentzel (2002) found a positive correlation between classroom grades and teacher fairness $(\mathrm{r}=.09, \mathrm{n}=452, \mathrm{p}<.05)$ and classroom grades and high expectations $(\mathrm{r}=.23, \mathrm{n}=452$, $\mathrm{p}<.001)$. From a hierarchical multiple regression, teaching dimensions accounted for significant variance of classroom grades $\left(\Delta \mathrm{R}^{2}=.10, \mathrm{p}<.001\right)$, with a combination of fairness, teacher motivation, rule setting, negative feedback and high expectations accounting for $10 \%$ of variation in positive academic performance. Negative feedback was found to be a significant negative predictor of classroom grades $(\beta=-.22, \mathrm{p}<.001)$ and high expectations was found to be a significant positive predictor of classroom grades $(\beta=.23, \mathrm{p}<.001)$. The research proposed that if 
teachers are trained to provide students with the teacher dimensions mentioned then this will lead to academic gains for their students.

\section{Reasons for teachers behaviours}

Of the six reviewed studies, one study analysed the reasons for teachers' behaviours to impact student motivation and therefore their test performance (Putwain \& Roberts, 2012). Putwain and Roberts (2012) found that the majority of Mathematics teachers agreed that students should be warned about failure (87\%) and its negative educational consequences $(67.5 \%)$. However, the vast majority of respondents (99.6\%) also agreed with the use of messages without any explicit fear content, such as reminders of approaching coursework deadlines and exam dates. The research also found with regards to efficacy appeals, most teachers agreed with all five items regarding the use of efficacy appeals. With regards to teachers' knowledge of domain beliefs, most teachers agreed that fear appeals may have unintended negative outcomes on students' motivation to pass their high stake examinations $(72.6 \%)$ and that messages intended by teachers to be encouraging may be perceived as threatening and demotivating by students $(84.6 \%)$.

The researchers found that teachers were more likely to endorse the use of fear appeals when they believed this would motivate students $(\mathrm{r}=.19, \mathrm{n}=234, \mathrm{p}<.01)$ and less likely to endorse the use of fear appeals when they believed these messages would be anxiety provoking for students $(\mathrm{r}=.14, \mathrm{n}=234, \mathrm{p}<.05)$.

In the present review, this was the only research paper which investigated the reason behind teachers' behaviour and the aim of this behaviour in influencing students' motivation and outcomes. Future research could further investigate the reasoning behind teacher motivational behaviour, and could explore how teachers come to know which behaviours to engage in for different student needs. School psychologists could play a key role in disseminating motivational theory to support teachers to see both the positive and negative impact of their language and behaviour on students' motivation and academic performance (Lipton, 1992).

\section{Summary}

Research suggests that teachers should generally avoid the use of fear appeals as a method to motivate students as it will more often have a detrimental impact on students' selfdetermined motivation and performance (Putwain \& Remedios, 2014; Wentzel, 2002). In order to motivate students and have a positive impact on students' performance, teachers should: 
provide academic support for competence and relatedness, academic pressure and behaviours which emphasise mastery goal orientation (LevpuÅÄek \& ZupanÄiÄ, 2009), create meaningful relationships with their students, show they are knowledgeable and deliver tasks that are relevant and in a variety of formats (Siegle et al., 2014), show caring behaviours to students in the classroom (Wentzel, 1997) and be perceived as fair and have high expectations of students; they also need to avoid providing a preponderance of negative feedback (Wentzel, 2002).

\section{Limitations of reviewed research}

Of the six reviewed studies, two focused on one subject, and so the findings cannot necessarily be generalised to other subjects (LevpuÅÄek \& ZupanÄï̈, 2009; Putwain \& Remedios, 2014); conversely, the other studies may have overlooked important subject-specific variations in student experience and perception. In two of the studies students were not asked to think of any teachers in particular therefore, students may have reported characteristics of teachers of subjects that were not included in the academic performance measure (Siegle et al., 2014; Wentzel, 1997). For one of the reviewed studies, the information from students was collected retrospectively, therefore there is possible attributional bias as the student participants all succeeded and could attribute this success to their teachers' behaviours, regardless of their actual effects at the time (Siegle et al., 2014). Consequently, it is difficult to compare the findings of this paper with the other five discussed. Finally the reviewed research focused mainly on quantitative and associative measures therefore the comprehensiveness and direction of influence between related factors cannot always be confidently demonstrated.

\section{Conclusions and Recommendations for Future Research}

This review has provided an original evaluation of the empirical literature relating to the motivational behaviours teachers engage in in respect of student performance in assessment. None of the methodologies of the studies reviewed actively engaged teachers in the research project and enabled them with the researcher to reflect upon and understand the purpose of their motivational behaviours. This is most likely an inevitable function of the focus of the review upon learning for assessment within the context of high-stakes tests and examinations (cf. Isaacs, 2010; Marshall, 2017). We propose that future research could usefully combine the more socially constructed approaches seen in teaching and learning practice to facilitate for teachers a more active and collaborative role, providing a professionally meaningful opportunity to develop 
relevant motivational strategies in the context of motivational theory and practice-based research ( Bracey, 1991; Furlong \& Oancea, 2005). Babkie and Provost (2004) found that a model of 'teachers as researchers' can increase teachers' own critical learning skills, support development of innovative approaches to instruction, and increase student success and performance. Given the likely cohort and subject student variation, as well as teacher transitions, ongoing school-based research could provide a locally relevant evidence-base and ultimately, through wider dissemination, support the development of generalizable screening procedures and pedagogic protocols. Interestingly, since the completion of this review in 2016, Flitcroft, Woods and $\underline{\text { Putwain (2017) have reported a collaborative action research project with a group of high school }}$ teachers to work with their students to understand the particular helpful and unhelpful strategies to support learner engagement through a learning programme aimed at high-stakes assessment (GCSE English and Mathematics). This study, however, made little use of motivational theory or outcomes of any of the research reported here for the consideration of either the students or the teachers themselves.

A significant limitation of five of the studies (LevpuÅÄek \& ZupanÄï̈, 2009; Putwain \& Remedios, 2014; Putwain \& Roberts, 2012; Wentzel, 1997, 2002) was a reliance upon solely quantitative measures (i.e. closed question questionnaires), limiting the categories of behaviours that teachers could be perceived to engage in. Furthermore, previous research has not directly linked teacher and student data to enhance internal validity. Future research using open-ended, qualitative data gathering methods with students and their teachers, would allow for a more detailed, dynamic and contextualised picture to be gained. 


\section{References}

Adderley, R.J., Hope, M.A., Hughes, G.C., Jones, L., Messiou, K., \& Shaw, P.A. (2015). Exploring inclusive practices in primary schools: Focussing on children's voices. European Journal of Special Needs Education, 30(1), 106-121.

Astleitner, H. (2000). Designing emotionally sound instruction : The FEASP-approach. Instructional Science, 28, 169-198.

Babkie, A. M., \& Provost, M. C. (2004). Teachers as Researchers. Intervention in School and Clinic, 39(5), 260-268. doi:10.1177/10534512040390050201

Bong, M., Cho, C., Ahn, H. S., \& Kim, H. J. (2012). Comparison of Self-Beliefs for Predicting Student Motivation and Achievement. The Journal of Educational Research, 105(5), 336352. doi:10.1080/00220671.2011.627401

Bracey, G. W. (1991). Teachers as Researchers. The Phi Delta Kappan, 72(5), 404-405.

Burton, D., Smith, M., \& Woods, K. (2010). Empowering children through training as social scientists: an example of a direct contribution to the curriculum. Educational Psychology in Practice, 26(2), 91-104.

Chamberlain, S., Daly, A.L., \& Spalding, V. (2011). The fear factor: Students' experiences of test anxiety when taking A level examinations. Pastoral Care in Education, 29(3), 193-205.

Choi, B.C.K. (1998). Perspectives on epidemiological surveillance in the $21^{\text {st }}$ century. Chronic Diseases in Canada, 19(4), 145-151.

Coe, R., Aloisi, C., Higgins, S., \& Major, L. E. (2014). What makes great teaching ? Review of the underpinning research. Retrieved December 17, 2015, from http://www.suttontrust.com/researcharchive/great-teaching/

Cohen, L. , Manion, L., \& Morrison, K. (2007) Research Methods in Education (6 ${ }^{\text {th }}$ edition). London: Routledge.

Covington, M. V. (1984). The Self-Worth Theory of Achievement Motivation : Findings and Implications. The Elementary School Journal, 85(1), 4-20.

Davis, R. (1993) When applicants rate the examinations: feedback from 2000 people. In B. Nevo 
and S. R. Jager (editors), Educational and psychological testing: The test taker's outlook. Goettingen (Germany): Hogrefe and Huber Publishers.

Deci, E. L., \& Ryan, R. M. (1991). A motivational approach to self: Integration in personality. In R. Dienstbier (Ed.), Nebraska Symposium on Motivation: Vol. 38. Perspectives on motivation (pp. 237-288). Lincoln: University of Nebraska Press.

Deci, E. L., \& Ryan, R. M. (1995). Human autonomy: The basis for true self-esteem. In M. Kemis (Ed.), Efficacy, agency, and self-esteem (pp. 31-49). New York: Plenum.

Deci, E. L., \& Ryan, R. M. (2000). The "What" and "Why " of Goal Pursuits : of Behavior Human Needs and the Self-Determination of Behavior. Psychology Inquiry, 11(4), 227-268.

Department for Children, School and Families (2008). Personalised Learning - A Practical Guide. Nottingham. Retrieved from http://webarchive.nationalarchives.gov.uk/20130401151715/http://www.education.gov.uk/p ublications/eOrderingDownload/00844-2008DOM-EN.pdf

Department for Children, Schools and Families (DCSF) (2010). Improving the quality of statements of special educational needs. Good practice in writing statements. Retrieved from: http://dera.ioe.ac.uk/765/7/sen_stmnts 0010610_Redacted.pdf

Department for Education (DfE) (2014b). Listening to and involving young people. Retrieved from: http://www.gov.uk/government/publications/listening-to-and-involving-children-andyoung-people

Department for Education. (2013). Improving the quality of teaching and leadership. Retrieved October 8, 2015, from https://www.gov.uk/government/policies/improving-the-quality-ofteaching-and-leadership

Dweck, C. S. (1999). Caution - Praise Can Be Dangerous. American Educator, Spring, 4-9. Retrieved from https://www.aft.org/pdfs/americaneducator/spring1999/PraiseSpring99.pdf

Flitcroft, D., Woods, K., \& Putwain (2017). Developing practice in preparing students for highstakes examinations in English and Mathematics. Educational and Child Psychology, 34(3), $\underline{7-19 .}$

Furlong, J., \& Oancea, A. (2005). Assessing Quality in Applied and Educational Research: A 
Hattie, J., \& Timperley, H. (2007). The power of feedback. Review of Educational Research, $77(1), 81-112$.

HM Government (2002). Education Act. Retrieved from: http://www.legislation.gov.uk/ukpga/2002/32/contents

Isaacs, T. (2010). Educational assessment in England. Assessment in Education: Principles, Policy \& Practice, 17(3), 315-334.

LevpuÅÄek, M. P., \& ZupanÄiÄ, M. (2009). Math Achievement in Early Adolescence. Journal of Early Adolescence, 29(4), 541-570.

Lipton, D. S. (1992). How to maximize utilization of evaluation research by policymakers. Annals of the American Academic of Political and Social Science, 521, 175-188.

Marshall, B. (2017). The politics of testing. English in Education, 51(1), 27-43.Mathews, J.C. (1985). Examinations: A commentary. London: George Allen \& Unwin.

Mathews, J.C. (1985). Examinations: A commentary. London: George Allen \& Unwin.

Meyer, B., Haywood, N., \& Sachdev, D. (2008). Independent Learning: Literature Review. 
Moher, D., Liberati, A., Tetzlaff, J., \& Altman, D. G. (2009). Preferred reporting items for systematic reviews and meta-analyses. PLoS Medicine, 6(7), 1-6.

Organisation for Economic Co-operation and Development. (2000). Motivating Students for Lifelong Learning. Paris: Publishing Centre for Educational Research and Innovation. Retrieved from http://www.oecd-ilibrary.org/education/motivating-students-for-lifelonglearning_9789264181830-en

Pekrun, R. (2000). A social cognitive, control-value theory of achievement emotions. In J. Heckhausen (Ed.), Motivational psychology of human development (pp. 143-163). Oxford, England: Elsevier.

Pekrun, R. (2006). The control-value theory of achievement emotions: Assumptions, corollaries, and implications for educational research and practice. Educational Psychology Review, 18, $315-341$.

Pekrun, R., Frenzel, A. C., Goetz, T., \& Perry, R. P. (2007). The control-value theory of achievement emotions: An integrative approach to emotions in education. In P. A. Schutz \& R. Pekrun (Eds.), Emotion in education (pp. 13-36). Burlington, MA: Academic Press.

Pekrun, R., \& Stephens, E. J. (2010). Achievement emotions: A control-value approach. Social Personal Psychology Compass, 4, 238-255.

Putwain, D. W., \& Remedios, R. (2014). The scare tactic: Do fear appeals predict motivation and exam scores? School Psychology Quarterly: The Official Journal of the Division of School Psychology, American Psychological Association, 29(4), 503-16. doi:10.1037/spq0000048

Putwain, D. W., \& Roberts, C. M. (2012). Fear and efficacy appeals in the classroom: the secondary teachers' perspective. Educational Psychology, 32(3), 355-372. doi:10.1080/01443410.2012.659845

Rodway, C., Tham, S.G., Ibrahim, S., Turnbull, P., Windfuhr, K., Shaw, J., Kapur, N., \& Appleby L. (2016). Suicide in children and young people in England: A consecutive case series. The Lancet 3(8), 751-759.

Ryan, R. M., \& Deci, E. L. (2000). Self-determination theory and the facilitation of intrinsic motivation, social development, and well-being. American Psychologist, 55(1), 68-78. 
Schunk, D., Pintrich, P. R., \& Meece, J. L. (2008). Motivation in education: Theory, research, and applications (3rd ed.). Upper Saddle River, NJ: Pearson Education.

Schunk, D. H. (1989). Social cognitive theory and selfregulated learning. In B. J. Zimmerman \& D. H. Schunk (Eds.), Self-regulated learning and academic achievement: Theory, research, and practice (pp. pp. 83-110). New York: Springer Verlag.

Scott, S., Webber, C.F., Lupart, J.L., Aitken, N., \& Scott, D.E. (2014). Fair and equitable assessment practices for all students. Assessment in Education: Principles, Policy \& Practice, 21(1), 52-70.

Shulman, S. L., \& Sykes, G. (1986). A national hoard for reaching? In search of a boldslandard. A reportforthe task force on teaching as a profession. New York: Carnegie Corporation.

Siegle, D., Rubenstein, L. D., \& Mitchell, M. S. (2014). Honors Students' Perceptions of Their High School Experiences: The Influence of Teachers on Student Motivation . Gifted Child Quarterly, 58 (1 ), 35-50. doi:10.1177/0016986213513496

Spielhofer, T., Walker, M., Gagg, K., Schagen, S., \& O’Donnell, S. (2007). Raising the participation age in education and training to 18: Review of existing evidence of the benefits and challenges. Retrieved December 17, 2015, from http://webarchive.nationalarchives.gov.uk/20130401151715/http://www.education.gov.uk/p ublications/eOrderingDownload/DCSF-RR012.pdf

Stipek, D. (2010). How Do Teachers' Expectations Affect Student Learning. Retrieved September 14, 2015, from http://www.education.com/reference/article/teachersexpectations-affect-learning/

Stobart, G. (2008). Testing times: The uses and abuses of assessment. Abingdon, Oxon: $\underline{\text { Routledge. }}$

Tamir, P. (1987). Subject Matter and Related Pedagogical Knowledge in Teacher Education. Teaching and Teacher Education, 4(2), 99-110.

United Nations (UN) (1989). Convention on the rights of the child. Geneva: United Nations. Retrieved from http://www.ohchr.org/EN/ProfessionalInterest/Pages/CRC.aspx. 
Wallace, M. \& Wray, A. (2011). Critical Reading and Writing for Postgraduates (2 ${ }^{\text {nd }}$ edition). London: Sage Publications.

Wentzel, K. R. (1997). Student motivation in middle school: The role of perceived pedagogical caring. Journal of Educational Psychology, 89(3), 411-419. doi:10.1037/00220663.89.3.411

Wentzel, K. R. (2002). Are effective teachers like good parents? Teaching styles and student adjustment in early adolescence. Child Development, 73(1), 287-301.

doi:http://dx.doi.org/10.1111/1467-8624.00406

White, J., \& Rae, T. (2016). Person-centred reviews and transition: An exploration of the views of students and their parents/ carers. Educational Psychology in Practice, 32(1), 38-53. DOI: $10.1080 / 02667363.2015 .1094652$

Williams, J., Ryan, J. \& Morgan, S. (2014). Lesson study in a performative culture. In Teacher Learning in the Workplace: Widening Perspectives on Practice and Policy (pp. 141-157). Dordrecht: Springer.

Woods, K. (2003) 'Equality of Opportunity Within the Examinations of the General Certificate of Secondary Education', Psychology of Education Review 27(2): 3-16.

Zimmerman, B. J. (1989). A social cognitive view of self-regulated academic learning. Journal of Educational Psychology, 81, 329-339.

Zimmerman, B. J. (2002). Becoming a Self-Regulated Learner: An Overview. Theory Into Practice, 41(2), 64-70. doi:10.1207/s15430421tip4102_2 